\title{
On Practical Ability Training of Hydrology and Water Resources Engineering Major
}

\author{
Kong Ke \\ College of Resources and Environment, University of Jinan, Jinan, China \\ koker@sohu.com
}

\begin{abstract}
The development of water conservancy cause needs more and more engineering technical personnel. Universities concerned should adapt to this situation and reinforce the practical ability training of the hydrology and water resources engineering major. Based on the major characteristics and the industry requests, the contents and aim of the practical ability training of hydrology and water resources engineering majors are analyzed, and the basic condition is promoted that inspiriting the teacher's initiative to build the proper interacting relation of teaching and learning, and it is stated that the effective methods to obtain the training aim include establishing the demand oriented course system, consummating the multilevel links of practical teaching, and developing the student professional science-create activities.

Index Terms - hydrology and water resources engineering, contents, conditions, methods
\end{abstract}

\section{Introduction}

China is facing serious water resources problems so that the traditional water conservancy is changing to the new work type which orients to the sustainable usage of water resources. This conversion simulates the development of the hydrology and water resources engineering major. The need for water resources professionals is increasing, but now so many college students are difficult to find jobs. One of the reasons is that those students' practical ability are not enough to adapt the requests of water industries which undertake engineering work such as water conservancy construction, design, planning and need technical personnel. Universities which have the hydrology and water resources engineering college should take this situation as a turning point to reinforce the teaching of students' practical ability and raise the education level. The hydrology and water resources engineering major is synthetical and its teaching contents cover many subjects as water resources, civil engineering, geology, environment science, geography, computer science, economics and management. The students usually have broad theoretical knowledge, but the practical training is relatively lacked because of the limitation of the whole class hours. This contradiction is more serious under current condition, and how to taking the actual requests of employing units into account when arranging the major courses is because an important problem[1][[2]. Li Duo summed the practical training experience of development internship bases[3]. Wang Li-zhen took ability training as the core of education and investigated the water conversation employing systems in Tianjing city and
Huabei district. Through summary and analysis, the reform of theoretical and practical teaching was carried out and achieved good effects[4]. $\mathrm{Zu}$ bo promoted some advices that optimization teaching system, increasing practical course and open laboratories on the perspectives of course arrangement, employing situation and practical teaching[5], and so on. It is worth to discuss that the practical ability of the hydrology and water resources engineering major has its characteristics so that in order to obtain better effects, the teachers should understand the connotation and aim of the practical ability training of hydrology and water resources engineering majors, and therefore take measures properly.

\section{Contents and conditions of practical ability training of hydrology and water resources engineering major}

\section{A. Contents and aims of practical ability training}

The practical ability of hydrology and water resources engineering major is the ability of using theoretical knowledge to solve practical ability. Water conservancy profession is engineering and technology profession, but not like such professions as mechanics, electrics, chemical industry, it deal with the natural rainfall, river, runoff, and soil, et al, which are on large scale and not controlled by human. We can only recognize them not change them, so the main task of water resources work is to study the natural laws. Unlike those pure natural science as meteorology and astronomy, water resources profession always comes down to the engineering measures, which means to using proper engineering construction and operation to dispatch and store water, make water resource effective and reduce or avoid flood and drought. The hydrology and water resources engineering is foundation of water conservancy, it undertake the task of recognize hydrological laws and serve for the water engineering, i.e. to provide basis for the engineering's design, construction and operation. We can not completely acquire the natural laws of water resources and have inadequate technology methods which can accurately describe such laws, so the theoretical parts of hydrology and water resources engineering refer to broad nature science and complicate math tools, at same time its application parts must be comparative elastic. Sometimes it is needed to use accurate and complicate methods and sometimes experienced methods. The two kinds of methods have different advantages and vary with time, which make major contents very immense. For example, there are hundreds

\footnotetext{
* This work is supported by Teaching research project of College of Resources and Environment University of Jinan(ZHJY1206)
} 
kinds of hydrological model, from the simple unit-graph model with one variable to the complicate physical model with hundreds of variables. Different methods are according to different situation, emphasize some main natural laws and have different applications and degree of difficulties. The students in hydrology and water resources engineering major must have the ability that understanding the principles of methods, acquirement the basic steps, understanding the application ranges, choosing proper and simple methods to solve ordinary problems and having comparatively reasonable thoughts for complicate problems, which is the basic contents of practical ability training of hydrology and water resources engineering major because such ability can make them smoothly take part into water conservancy works.

\section{B. Basic conditions of practical ability training}

The practical teaching is to make students have abilities above through orderly teaching activities. Commonly, there are three stages for students to acquire such abilities: at first, mastering theoretical knowledge, understanding the principles and application of theorems or equations in textbooks; second, guided with teacher, they solve some practical problems form easy to difficult, and then learn solutions of problems, compare the theoretical knowledge and practical knowledge to profound the understanding of textbook contents and consequently form knowledge networks; at last, through enough exercitations, they set up right ways to solve problem, obtain the work skills. When they face complicate problems, they can initiatively study, explore and create the right solutions.

In order to complete such procedures, besides hardware the basic conditions a college mast have are software, i.e. the teachers and students have common ideas of ability training, and the proper interacting relation of teaching and learning must be established. Teaching and learning are two sides of education system. The teachers are knowledge distributors, so they always guide students on high level above students and help students realize the cognition transform form sensibility to reasonability and to practical ability. Teachers should firstly mentally recognize the importance of training students' practical ability and create more chance by teaching methods in class and out class to let students have more chance of practice, instigate them to explore and create, train them to have measure of thinking problem, steps of analysis and skills of handling problems. On the contrary, although the students are under the instructions of teacher, their learning is independent. Especially for the practical ability training, simple understanding of textbook is not enough to obtain abilities, and the students themselves must think over and practice. The teachers can only guide them and can not replace them. From this point of view, study is the main contradiction in education, which stipulates the teaching's property, method and procedure. So, teaching and study are whole body, effect each other and promote each other. In education procedure of hydrology and water resources engineering major, it is necessary to set up proper interacting relation of teaching and learning. Teachers and students are all positively teaching and studying, only which can ensure teachers and students try together to find problems, discuss knowledge and promote practical training effects.

\section{Effective methods to obtain the training aim}

\section{A. Establishing the demand oriented course system}

A perfect course system is the good carrier of practical ability training. When schools draft emend the course plan, they should be opening i.e. not only let all the teachers enter into this work but absorb some experienced engineers, especial the technology administers in the employing units which once employed the graduates from the schools. All the participants teachers and engineers discuss together according to real job requirement, graduates' work ability, education conditions of schools and the develop trend of the discipline. The ability modules should be firstly defined according to the actual job demand ability; then be divided into ability points. These ability points with their corresponding knowledge points should be summed up and implanted into theoretical teaching course system and practical teaching course system. This opening procedure is so called demand oriented course system which effectively helps students realize the smooth transform from school to job, in details it contains two sides of problem as followed:

\section{Arrange courses properly}

There are differences among major course in different college, but the main course are same including geography, meteorology, principles of hydrology, engineering hydrology, hydrology statistics, hydraulics, water resources system analysis, water resource planning and management, groundwater hydrology, hydrology forecasting, environment science, water conservancy project, and so on. Practical engineering and technical personnel will be able to conduct hydrological calculation and forecast, as well as to engage in water resources planning and management, water protection, small and medium sized water conservancy design, construction and management, urban water supply, drainage and sewage treatment, and so on. But limited by the real equipments of schools and the total course hours, no school can arrange all the course and practical trainings above, the only way is to decide according to the actual situation. For those local university whose graduates' service unites are local department, the local demand for personnel is the main reason to take into account when begin their teaching plan. For example, in the downstream areas of the Yellow river, there is no hydraulic power and the flood threaten is not serious, the main work of water conservancy is farmland water conservancy, so the course such as irrigation, farmland project should be increased. If the school locates in the upper stream district where many power stations locate, it should added some courses like water power utility, power station economical operation and so on. 


\section{Allocation course hours properly}

When schools allocate course hours, they should balance the relation between the theoretical teaching and the practical teaching, and properly add study times for practical kinds of course to ensure the students have enough chance of practice. But it is true to set two many practical training course and study time. Now some education administers and teaching staffs have an impetuous idea that shrink the time of class lesson too more, even oblige the students working in the enterprises for a certain time before graduate. This idea has good aim, but it is not necessary and can not have any effect. The reasons are as follow: first, the major practical ability is not simple operation ability, but the flexible disposal capacity on the basis of understanding, which only can be achieved through the mastering of theoretical knowledge. The students who have little theoretical knowledge can not use knowledge correctly and can not creatively solve the new problems they never met before; second, the ability we asked in school is not as same as the ability the employer asked in enterprise. As mentioned above, the basic connotation of practical ability training of hydrology and water resources engineering major is to make the students smoothly take part into water conservancy works, not be experts, which can only be brought up by the temper of working time. No school education can real obtains this aim, so the rights way is to set it as an idea direction and not the real aim.

\section{B. Consummating the multilevel links of practical teaching}

University practical teaching includes teaching links as curriculum experiment, curriculum design, awareness practice, production practice, graduation thesis. The major ability requirements have multi-tiers. Some are basic ability, student must master them, such as drawing Tyson polygon, calculating using Muskingum method; and some only need to be known such as water demand forecast, and some only need to be known a little, such as water-use quota emendation. So practice teaching should also be different emphases, which complement each other, forming a multilayer teaching system.

Cognition practice is aims to help students build macroperceptual recognition of hydrology and water resources professional major. Through targeted cognition practice, students can increase interest in learning and enhance pride sense of their major, which can lay a good foundation for future professional knowledge learning. In organizing the cognition practice something should be done well: (1) Choosing good internship base. Cognition practice should not be carried out in schools but in the internship base in order to arouse students' professional interests. The internship base should contain abundant professional contents such as typical hydro-geological environment, integrated water resources engineering, large-scale construction in progress, and so on. As many colleges in northern Select Qinhuangdao as training base, colleges in Jinan may choose southern mountain areas to establish internship base where the hydro-geological types are abundant, and there Wohushan reservoir, Jinxiuchuan Reservoir, and Jinxiuchuan irrigation channels, Fenshuiling water factory and other projects; (2) Arrangement good room and board for students, and ensure them safety;(3) College should ask instructors to organize internship documents including practice outlines, practice plan and practice guide book; and should plan to accumulate field data such as geological data, photos, video, rainfall data, runoff record, water conservancy project drawings, design reports, operating records, and so on. After every time of internship, the experiments must be well summed up to improve training data and to improve practice guide book.

The curriculum experiment is basic requirement, contains principle and methods ought to be mastered by students. Through such course, students not only to strengthen the understanding of theoretical knowledge, such as the seepage experiments, but also familiar with some practical engineering objects, such as weir flow experiments, water jump energy dissipation experiments. Teachers first should organize the students strictly in accordance with requirements of the outline of each experiment, careful guide the students, earnestly comment lab reports, and then innovate positively, design more open and comprehensive experiments, encourage students to raise and resolve issues, let students apply their knowledge to analyze experimental data and arrange extra training for the students who have higher ability. College laboratory should take students as basic service objects, and provide sufficient conditions for them such as experimental field, laboratory equipment, personnel and so on. For the basic courses such as hydraulics experiment, each student ought to operate separately; for the comprehensive experiment such as the hydrological cycle, students ought to operate in small group.

Production practice is important part of students' practical abilities training. It is important to development the style of production-study-research which can take both advantages of school system local industry. The schools can improve teaching quality and students' practical ability, innovation and collaboration capabilities, and the local industries can take part in the students teaching, train and choose graduates they needed. Currently for some reason to find a good unit for students to carry out production practice is not a easy thing. So the school and teacher should pay more attention to this. During the internship, the school's instructors and production units must be adequately exchange information, avoid the situation that the students have nothing to do in the practice. It is better for teachers to give students some issues before the internship because this can make students pay more attention to the work their faced and to find the solution of issues positively during the practice.

Graduate thesis is last part of education in school. The instructors should choose some practical topic which combine with the actual production for students' thesis. Instructors who have proper research project may choose some easy issue for the students, but try to avoid overview discussion, pure method issue or macroscopic topic. The aim of writing thesis is not only make students sum up and use the knowledge they learnt 
during four years of study, but lay the foundation for their future work.

\section{Developing the student professional science-create activities}

In addition to the normal teaching methods mentioned above, students science-create activity outside the class is also an effective way to improve students' practical abilities. Through the activities such as "SRT", "Challenge Cup" and so on, we can attract students to discover and solve problems, which not only bring up the practical abilities of students, but also promote ability of teamwork. All of these are very important for their future work good. Student science-create activity should be combined with profession to have more effects. Some students are interested in some kinds of special issues, which have important sense as well, but because such issues are not professional questions, the students have little knowledge about them and do their teachers. Under this kind of circumstance, they can hardly have achievements, which only can waste time and reduce their enthusiasm to take part in science-create activity. Water resources issues are the current hot issues, from the world to Jinan City, there are many issues worth to be discussed. In Jinan city, for example, there are questions like spring protection, the Yellow River reservoir water safety, urban flood protection, etc. In addition, the hydrology and water resources engineering is a developing discipline, research findings from other disciplines continue to be introduce into it and therefore form many new areas of research and technology system, such as multi-objectives water allocation, regional water economical planning, etc. So, students always can find proper professional titles for their science-create activity outside the class to play their creativity and improve their practical ability.

The professional science-create activities can not be without the guidance of professional teachers. It is necessary to encourage teachers put more attentions in leading students to learn and explore together, which can be beneficial for students, as well be useful for the promotion of teachers' level of scientific research. In short, to build the proper interacting relation of teaching and learning is the basic condition of the major practical ability training.

\section{Remarks}

Practical training is a systematic work. In order to better adapt to the employing requirements, it is necessary to firstly recognize the contents and aim of the practical ability training of hydrology and water resources engineering major. To obtain the training aim, the basic condition is to build the proper interacting relation of teaching and learning, and the effective ways include establishing the demand oriented course system, consummating the multilevel links of practical teaching, and developing the student professional science-create activities.

The development of society asks for more effective practical ability teaching for students so the universities must develop their teaching system. Facing the actual front work of water resources construction, production and services, more good professionals who not only have theoretical knowledge but also have practical ability and creative ideas should be brought up to contribute to the development of national water resource causes.

\section{References}

[1] Zhou Xun. "Some Ideas on the Modification of Undergraduate Programs of the Speciality of Hydrology and Water Resources Engineering," Chinese Geological Education, vol.14, no.1, pp. 56-58, January 2005.

[2] Sun Shou-guo, Jiang Xiao-hui. "Reflection on Training the Application Oriented Students of the Hydrology and Water recourse Major," Journal of Changchun Institute of Technology(Social Science Edition), vol.9,no.2,pp.81-82,March 2008.

[3] Li Duo, Li Fang-hong, Fang Xiao-feng. "Discussion on the Practice Teaching for the Specialty of Hydrology and Water Resources Engineering," Journal of Shijiazhuang University of Economics, vol.31,no.4,pp. 127-129,April 2008.

[4] Wang Li-zhen, Sun Shu-hong. "'On teaching reform for hydrology and water resources based on ability training," China Electric Power Education,pp.75-77,December 2010:

[5] Zu Bo, Wang Wei. "Study on Educational Reform of Hydrology and Water Resources Engineering Course", Environmental Science and Management, vol.36, no.6, pp. 189-192, June 2011. 